\title{
Responsible Regulation of the Religious Slaughter of Animals
}

\author{
Ven. Alex Bruce \\ Associate professor, The Australian National University College of Law
}

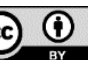

Received: April 2019

Accepted: April 2019

Recommended citation. Responsible Regulation of the Religious Slaughter of Animals, dA. Derecho Animal (Forum of Animal Law Studies) 10/2 (2019) - DOI https://doi.org/10.5565/rev/da.433

\begin{abstract}
One of the more intractable issues associated with animal law and ethics concerns responsibly regulating the slaughter of animals according to the requirements of the Jewish religious tradition and some interpretations of the Islamic religious tradition. Most Western liberal democratic societies require animals to be stunned before slaughter to ensure they are insensible when killed. However, the Jewish tradition and many interpretations of the Islamic tradition prohibit pre-slaughter stunning. In these traditions, animals are killed according to specific religious rituals that involve cutting the animal's throat and permitting it to exsanguinate without prior stunning. These requirements therefore come into direct conflict with Statutes, Codes and Regulations of many Western countries intending to give expression to animal welfare policies by requiring pre-slaughter stunning. However, such practices are also protected by international and domestic human rights instruments guaranteeing freedom of religious practice and expression. Recent decisions of European Courts demonstrate the difficulties that arise when countries attempt to regulate this conflict. In exploring several of these recent decisions, this article intends to outline the parameters of this conflict and to suggest a potential way forward to responsible regulation of such practices.
\end{abstract}

Keywords: Animal Welfare; Religious Slaughter; EU Jurisprudence; Halal and Kosher.

Resumen - Regulación responsable del sacrificio de los animales de acuerdo con ciertos ritos religiosos

Una de las cuestiones más difíciles, asociadas con el Derecho Animal y la ética, se refiere a la regulación responsable del sacrificio de los animales de acuerdo con los requisitos de la tradición religiosa judía y algunas interpretaciones de la tradición religiosa islámica. La mayoría de las sociedades democráticas liberales de Occidente, exigen que los animales sean aturdidos antes de ser sacrificados, para asegurar que estén insensibles cuando son sacrificados. Sin embargo, la tradición judía y muchas interpretaciones de la tradición islámica prohíben el aturdimiento previo a la matanza. En estas tradiciones, los animales se sacrifican de acuerdo con rituales religiosos específicos, que implican cortar la garganta del animal y permitirle desangrarse sin aturdimiento previo. Por lo tanto, estos requisitos entran en conflicto directo con los Estatutos, Códigos y Reglamentos de muchos países occidentales que pretenden dar expresión a las políticas de bienestar animal exigiendo el aturdimiento previo al sacrificio. Sin embargo, esas prácticas también están protegidas por instrumentos internacionales y nacionales relativos a los derechos humanos que garantizan la libertad de la práctica y la expresión religiosas. Las recientes decisiones de los tribunales europeos, demuestran las dificultades que surgen cuando los países intentan regular este conflicto. A través del estudio de varias de estas recientes decisiones, este artículo pretende esbozar los parámetros de este conflicto y sugerir una posible manera de avanzar hacia una regulación responsable de tales prácticas.

Palabras clave: Bienestar animal; Sacrificio religioso; Jurisprudencia de la UE; Halal y Kosher. 


\section{Contents}

1. Introduction

2. The Issues in Context

3. Debating Inconsistency

4. An Inconsistency Protected

5. Consumer Rights and Labelling Initiatives

6. Labelling Resurrected?

7. Conclusions

\section{Introduction}

Humans have never regarded food in merely utilitarian terms; as simply a resource for the body's production of necessary energy. Since the earliest civilizations, humans have invested food, its preparation and sharing with others in the form of communal meals, with both religious and social significance. Easily recognisable examples include the Jewish Seder Meal celebrated in remembrance of Passover, and the early Christian Agape Feast and Eucharistic celebration. In contemporary times, food-choices reflect both lifestyle and ethical preferences and are thus "linked with expressions of cultural identity." In this context, food practices enable individual, religious and cultural groups to both define and reinforce their sense of identity and belonging. ${ }^{2}$ This is especially so where religious traditions prescribe specific practices or techniques relating to the preparation and consumption of certain foods. But what happens if those specific foods practices or techniques come into conflict with secular values held by wider society? How do secular western liberal democratic countries attempt to responsibly negotiate simultaneous commitments to religious and cultural diversity on the one hand, and to secular values potentially inconsistent with religious or cultural food practices on the other?

\section{The Issues in Context}

Each year, since the start of the $21^{\text {st }}$ Century, over 100 billion animals, including 50 billion chickens, have been slaughtered to provide food for humans. ${ }^{3}$ It has been estimated that " $99 \%$ of all domesticates are commodities in animal agricultural" that are killed and transformed into food products for humans. ${ }^{4}$ These numbers are expected to dramatically increase over the next three decades as the world's population also dramatically increases. One of the drivers of this demand is a growing middle-class within developing countries whose diet is changing to include more animal-based products including meat, eggs and milk. By 2020, it is estimated that inhabitants in developing countries will consume 107 million metric tons (mmt) more meat and $177 \mathrm{mmt}$ more milk than they did in the period $1996-1998 .^{5}$

Another factor driving increased demand for meat products is the growth of Muslim populations world-wide. The Muslim population is expected to rise by approximately 35\% from 1 billion in 2010 to approximately 2.2 billion by 2030 thereby making up around $36.4 \%$ of the world's population. ${ }^{6}$ The worldwide growth in Muslim population has generated global demand for Halal meat products and a corresponding increase in both live-animal and chilled meat exports from non-Muslim countries to meet this demand. ${ }^{7}$ It is estimated that the current global market for Halal meat is worth approximately USD $\$ 77$

\footnotetext{
${ }^{1}$ KURTH, L., GLASBERGEN, P., Dealing with Tensions of Multiculturalism: The Politics of Religious Slaughter in the Netherlands (2017) 20(4) European Journal of Cultural Studies 413.

${ }^{2}$ CANTARERO, L., ESPEITX, E., LACRUZ, MG. et al. Human Food Preferences and Cultural Identity: The Case of Aragon (Spain) (2013) 48 International Journal of Psychology 881.

${ }^{3}$ MIELE, M., Killing Animals for Food: How Science, Religion and Technologies Affect the Public Debate About Religious Slaughter (2016) 1 Food Ethics 47.

${ }^{4}$ WILliAMS, E., DEMELlO, M., Why Animals Matter: The Case for Animal Protection, 2007, Prometheus Books, New York, United States at 14.

${ }^{5}$ DELGARDO, C., Rising Consumption of Meat and Milk in Developing Countries has Created a new Food Revolution (2003) 133 Journal of Nutrition 3907S. (Quoted in Miele above at 48.)

${ }^{6}$ GRIM. B., KARIM, M., The Future of the Global Muslim Population: Projections for 2010-2030, Pew Research Centre, Washington, United States. <https://www.pewforum.org/2011/01/27/the-future-of-the-global-muslim-population/> (accessed 7 April 2019)

${ }^{7}$ FAROUK, M., PUFPAFF, K., AMIR, M., Industrial Halal Meat Production and Animal Welfare: A Review (2016) 120 Meat

20 Derecho Animal. Forum of Animal Law Studies, vol. 10/2
} 
billion annually ${ }^{8}$. Both India and Australia, non-Muslim countries, export significant quantities of live animals and meat prepared according to Halal guidelines to Muslim countries, especially in the Middle East and Asia.

Most Western liberal democratic societies have enacted Statutes, Codes or Regulations concerning the locations and methods by which animals are slaughtered for food. In the European Union, Art. 4(1) of Council Regulation (EC) 1099/2009 provides that prior to slaughter, animals must be rendered unconscious through an approved method of stunning. The intention of Art.4(1) is to ensure that the animal is unconscious and therefore insensible to any pain during the slaughter process. However, in order to produce Halal and Kosher meat, ritual slaughter in the Jewish and some Islamic traditions is performed without the animals being stunned into insensibility prior to slaughter. In both traditions, ritual slaughter involves a specially trained operator using a very sharp knife to cut the animal's throat permitting the animal to exsanguinate (bleed out). ${ }^{9}$

Shechita is the term given to the Jewish religious practice of slaughtering animals and poultry in a manner that renders their meat ritually fit for consumption. The slaughter process involves a trained worker (called a "shochet") using a very sharp knife to cut the trachea, oesophagus, carotid arteries and jugular vein of an un-stunned, fully conscious animal that is then exsanguinated, or bled to death. Shechita UK,'s May 2009 publication A Guide to Shechita states that; "the time-hallowed practice of shechita, (is) marked by compassion and consideration for the welfare of the animal". ${ }^{10}$ According to Shechita UK, the cutting of an animal's throat; “...causes an instant drop in blood pressure in the brain and immediately results in the irreversible cessation of consciousness. Thus, shechita renders the animal insensible to pain". ${ }^{11}$ Likewise, the Islamic tradition maintains that its processes of ritual slaughter producing Halal meat are "foundationally important for halal consumers and therefore all spiritual aspects must be met including animal welfare standards of the meat production." 12

However, if these claims are correct, why does the un-stunned ritual slaughter of animals generate such heated debate? At least one answer to that question involves the accuracy of claims that un-stunned slaughter does not cause animals greater pain than pre-slaughter stunning. Does un-stunned slaughter involve a greater degree of pain? And if so, is there a fundamental inconsistency between aspiration and practice?

\section{Debating Inconsistency}

At the heart of Art. 4(1) of Council Regulation (EC) 1099/2009 and associated European Union Instruments such as the Protocol 33 to the Treaty Establishing the European Union is the welfare of animals, particularly at the point of slaughter. It has been argued that un-stunned ritual slaughter causes animals to experience greater pain than if those animals had been stunned. However, both the Islamic and Jewish traditions insist on compassion being shown to animals and maintain that methods of un stunned slaughter are consistent with animal welfare. ${ }^{13}$

In fact, recent scientific studies suggest that un-stunned ritual slaughter does cause significant animal welfare problems including stress and pain. In 2002, the Federation of Veterinarians of Europe ("FVE") reviewed the scientific literature concerning un-stunned slaughter, concluding that the practice of slaughtering animals without prior stunning is unacceptable under any circumstances. The FVE, noted that slaughter without stunning increases the time to loss of consciousness, sometimes up to several minutes and that during this period of consciousness the animal can be exposed to pain and suffering. ${ }^{14}$

These findings were confirmed by a Report in 2009 in Australia and New Zealand. Investigators from Monash University, the University of Melbourne, the Victorian Department of Primary Industries and Massey University in New Zealand concluded: "taken together the conclusions above indicate that because

Science 60 .

${ }^{8}$ D'AMICO, P., VITELLI, N. et al, Meat from Cattle Slaughtered Without Stunning Sold in the Conventional Market Without Appropriate Labelling: A Case Study in Italy (2017) 134 Meat Science 1.

${ }^{9}$ For a more detailed description see: ZOETHOUT, C., Ritual Slaughter and the Freedom of Religion: Some Reflections on a Stunning Matter (2013) 35(3) Human Rights Quarterly 651 at 655ff.

${ }^{10}$ Shechita UK, A Guide to Shechita, May 2009, at p 3

$<$ https://www.shechitauk.org/wp-content/uploads/2016/02/A_Guide_to_Shechita_2009_01.pdf $>$ (accessed 7 April 2019).

${ }^{11}$ Ibid.

${ }^{12}$ FAROUK, M., PUFPAFF, K., AMIR, M., Industrial Halal Meat Production and Animal Welfare: A Review (2016) 120 Meat Science 60

${ }^{13}$ LERNER, P., RABELlO, A., The Prohibition of Ritual Slaughtering and Freedom of Religion of Minorities (2006/2007) 22 Journal of Law and Religion 1.

${ }^{14}$ Federation of Veterinarians of Europe, Slaughter of Animals Without Stunning, FVE02/104, 2002

$<$ https://www.fve.org/cms/wp-content/uploads/fve_02_104_slaughter_prior_stunning.pdf $>$ (accessed 7 April 2019) 
the slaughter of sheep by ventral-neck cutting without prior stunning is likely to cause pain, slaughter of sheep without stunning poses a risk to animal welfare in the period between the time of the neck cut and the time of loss of awareness." 15

Award winning co-author of the Report, Associate Professor Craig Johnson concluded that the research "is the best evidence yet that it is painful." 16 More recent scientific studies confirm the Report's results. For example, a 2009 New Zealand study concluded that there was a period following slaughter where the neck incision represented a "noxious stimulus"; that is, a pain-causing event. ${ }^{17}$ Likewise, a 2010 Royal Veterinary College study demonstrated the agonies suffered by animals whose throats had been cut without stunning for halal meat production. ${ }^{18}$

Despite these inconsistent positions about the nature and extent of pain suffered by un-stunned animals at the point of slaughter, "the deeper issue that must be confronted arises from the fact that even when best commercial practices are followed, enormous numbers of animals experience pain or distress in the final period of their life regardless of whether they are killed by halal, kosher or secular methods of slaughter." 19

\section{An Inconsistency Protected}

Despite inconsistent views on the issue of suffering, the practice of religious ritual slaughter of animals is protected in most Western countries. Article 9 of the European Convention of Human Rights ("ECHR"), Article 10 of the European Charter of Fundamental Rights and Article 18 of the International Covenant on Civil and Political Rights specifically protect freedom of religion, conscience and belief, including the freedom to practice according to the requirements of one's religion. In Cha'are Shalom Ve Tsedek v. France, the European Court of Human Rights in 2000 noted that the practice of ritual slaughter was a manifestation of the freedom of religious practice protected by Art. 9 of the ECHR. ${ }^{20}$

The primacy of Art. 9 over domestic legislation was affirmed in 2014 by the Constitutional Tribunal of Poland in Judgement K52/13. In a sharply divided decision, the Court ruled that a provision of the Polish Animal Protection Act 1997 prohibiting certain forms of religious slaughter of animal was contrary to those provisions of the Polish Constitution enshrining Art. 9 of the ECHR. ${ }^{21}$

Nevertheless, not all restrictions or limitation imposed upon the practice of the religious slaughter of animals offends Human Rights Instruments. In 2018, the Court of Justice of the European Union (Grand Chamber) in Liga van Moskeeën en Islamitische Organisaties Provincie Antwerpen VZW held that confining religious slaughter to "approved slaughterhouses" did not restrict religious practice in contravention of Art.10 of the European Charter of Fundamental Rights or Art. 13 of the Treaty on the Functioning of the European Union. ${ }^{22}$ In fact, the Court in the In Cha'are case held that the refusal by the French Government to permit an orthodox Jewish community to establish its own abattoirs did not contravene the protections afforded by Art. 9 of the ECHR. The Court held that since the Jewish community could import ritually pure meat from Belgium, there was no restriction on freedom of religion. ${ }^{23}$

\section{Consumer Rights and Labelling Initiatives}

One of the little-known consequences of the religious ritual slaughter of animals in both the Jewish and Islamic traditions is the extent to which Halal and especially Kosher meat products enter the wider food distribution chain. The UK Halal Food Authority noted that while Muslims amount to approximately $3 \%$ of the UK population, Halal meat actually makes up approximately $25 \%$ of the domestic market for meat. ${ }^{24}$ In

\footnotetext{
15 HEMSWORTH, PH., FISHER, AD., MELLOR, DJ., JOHNSON, CB., A Scientific Comment on the Welfare of Sheep Slaughtered without Stunning, 14 July 2009 at paragraph 3.

${ }^{16}$ COGHLAN, A, Animals Feel the Pain of Religious Slaughter, 13 October 2009, New Scientist.

${ }^{17}$ GIBSON, TJ., JOHNSON, CB., MURRELL, JC., HULL, CM., MITCHINSON, SL., STAFFORD, KJ., JOHNSTONE, AC., MELLOR, DJ., Electroencephalographic Responses of Halothane-Anaesthetised Calves to Slaughter by Ventral-Neck Incision Without Prior Stunning (2009) 57 (2) New Zealand Veterinary Journal 77.

18 GREGORY, NG., FIELDING, HR., VON WENZLAWOWICZ, M., VON HOLLEBEN, K., Time to Collapse Following Slaughter Without Stunning in Cattle (2010) 85 Meat Science 66.

${ }^{19}$ STEIN, B., It's Not Just About the Knife: Religious and Secular Killing for Meat (2015) 1 UniSA Student Law Review 18 at 21.

${ }^{20}$ Cha'are Shalom Ve Tsedek v. France App No. 27417/95 (ECtHR, 27 June 2000).

${ }^{21}$ GLISZCZYNSKA-GRABIAS, A., SADURSKI, W., The Law of Ritual Slaughter and the Principle of Religious Equality (2016)

4 Journal of Law, Religion and State 233.

${ }^{22}$ Liga van Moskeeën en Islamitische Organisaties Provincie Antwerpen VZW Case C-426/16, 29 May 2018.

${ }^{23}$ ZOETHOUT, C., Ritual Slaughter and the Freedom of Religion: Some Reflections on a Stunning Matter (2013) 35(3) Human Rights Quarterly 651 at 665.

${ }^{24}$ LEVER, J., PUIG DELla BellaCASA, M., The Development of Halal and Kosher Meat Markets in the UK, 2010, The

22 Derecho Animal. Forum of Animal Law Studies, vol. 10/2
} 
addition, technical complexities associated with producing Kosher meat outside of Israel means that a significant quantity of meat, but particularly the hindquarters, are sold to non-kosher markets to be unintentionally purchased and eaten by non-Muslim and non-Jewish consumers. ${ }^{25}$

To what extent can Governments regulate the religious slaughter of animals to ensure supply-chain integrity? What regulatory initiatives can Governments implement to balance the right to continue the protected practice of religious slaughter of animals on the one hand, with the growing interest of consumers in animal welfare? Can Governments introduce a labelling scheme to achieve this balance?

A survey of 13,500 consumers in the EU conducted in 2015 by the Food Chain Evaluation Consortium (FCEC) revealed that $72 \%$ of consumers would be interested in receiving information about the method of slaughter of meat products they intended to buy. ${ }^{26}$ Clearly, non-Jewish and non-Muslim EU consumers feel they would benefit from such information. However, would a requirement imposed upon Islamic and Jewish communities to label meat products produced from ritually slaughtered animals constitute a form of discrimination in breach international Human Rights Instruments?

The issue of clearly identifying meat from animals slaughtered by halal or kosher methods was of significant concern to the European Parliament and in June 2010, the European Parliament voted on new food labelling laws. Titled On the Proposal for a Regulation of the European Parliament and of the Council on the Provision of Food Information to Consumers, ("the EU Resolution"), it contained "Amendment 205." 27 Amendment 205 required that meat and meat products derived from animals that have been ritually slaughtered, that is, slaughtered without prior stunning, must be labelled as such. The stated intention behind Amendment 205 was:

"EU legislation permits animals to be slaughtered without prior stunning to provide food for certain religious communities. A proportion of this meat is not sold to Muslims or Jews but is placed on the general market and can be unwittingly purchased by consumers who do not wish to buy meat derived from animals that have not been stunned. At the same time, however, adherents of certain religions specifically seek meat from animals which have been ritually slaughtered. Accordingly, consumers should be informed that certain meat is derived from animals which have not been stunned. This will enable them to make an informed choice in accordance with their ethical concerns."

What was at issue was labelling, not the ability of European Member States to prohibit the slaughter of animals for religious purposes without stunning. European Jewish and Islamic Groups initiated a wellorganised campaign against Amendment 205 alleging that it discriminated against religious practice as part of a "pan-European bias against Islam." 28 The campaign was successful and at its December 7, 2010 meeting the EU Council of Ministers rejected it. ${ }^{29}$

\section{Labelling Resurrected?}

Interestingly, in February 2019, the European Court of Justice ruled that minced beef patties that were Halal certified, could not be labelled as a product of "organic farming" or bear the "organic" label. The French Oeuvre d'assistance aux betes d'abattoirs ("OABA") had made an application to the French Minister for Agriculture for the prohibition of the advertising and marketing of beef products certified Halal and showing an "organic farming" label. Its application refused, and for various technical reasons, OABA found itself in a final appeal to the European Court of Justice.

OABA argued that the un-stunned slaughter of animals in producing Halal meat was inconsistent with relevant EC Regulations concerning organic production of food items. For example, Recital 1 of Regulation 834/2007 (On Organic Production and Labelling of Organic Products) emphasises "the application of high

University of Huddersfield <https://pure.hud.ac.uk/ws/portalfiles/portal/14280072/factsheet_market_uk.pdf $>$ (accessed 7 April 2019)

${ }^{25}$ D'AMICO, P., VITELLI, N. et al, Meat from Cattle Slaughtered Without Stunning Sold in the Conventional Market Without Appropriate Labelling: A Case Study in Italy (2017) 134 Meat Science 1 at 2.

${ }^{26}$ European Commission, DG Health and Food Safety, Study on Information to Consumers on the Stunning of Animals (2015) Final Report < http://www.ceasc.com/Images/Content/2643\%20Appendices.pdf $>$ (accessed 7 April 2019).

27 On the Proposal for a Regulation of the European Parliament and of the Council on the Provision of Food Information to Consumers 16 June $2010<$ http://www.europarl.europa.eu/sides/getDoc.do?type=REPORT\&reference=A7-20100109\&language $=\mathrm{EN}>$ (accessed 7 April 2019).

${ }^{28}$ New EU Labels for Halal and Kosher Foods Spark Anger, The National, 26 December 2010

$<$ https://www.thenational.ae/world/europe/new-eu-labels-for-halal-and-kosher-foods-spark-anger-1.501606> (accessed 7 April 2019)

${ }^{29}$ Council Agrees on New Labelling Rules for Food, Council of the European Union, 7 December 2010.

$<$ http://www.consilium.europa.eu/uedocs/cms_data/docs/pressdata/en/lsa/118258.pdf> (accessed 8 April 2019). 
animal welfare standards" in the production of organic food items ${ }^{30}$. Likewise, Recital 10 of Regulation 889/2008 (rules for the implementation of Council Regulation (EC) No 834/2007 on organic production and labelling of organic products with regard to organic production, labelling and control) states that one of the principles of organic farming is "to serve a high level of animal welfare." ${ }^{31}$ In essence, OABA argued that un-stunned slaughtering of animals did not comply with the high animal welfare standards established by the Regulations.

The various respondents to the appeal countered with the argument that the requirement of "high animal welfare standards" required by Regulation 834/2007 was not incompatible with ritual killing intended to guarantee the freedom to practice one's religion. Unsurprisingly the Court noted that "the matter of how to answer the claim that the 'organic farming' indication is not to be used for meat derived from animals that have been ritually slaughtered without pre-stunning, which is decisive for the outcome of the dispute in the main proceedings, raises serious difficulty in the interpretation of EU law." 32

Despite this acknowledged difficulty, the Court accepted OABA's argument, holding that "scientific studies have should that pre-stunning is the technique that compromises animal welfare the least at the time of killing." 33 Having accepted the force of the scientific evidence, the Court concluded that un-stunned slaughter of animals "does not allow the animal's suffering to be kept to a minimum" as required by Regulation 834/2007.

At least in the EU, meat products sourced from animals slaughtered according to Halal and Kosher procedures would seem to be ineligible for "organic" certification, purely on the basis of diminished welfare associated with un-stunned slaughter.

\section{Conclusions}

The implication of the Court's decision is significant because it represents high-level EC judicial recognition of the preponderance of scientific evidence that the un-stunned ritual slaughter of animals causes more pain to an animal than pre-stunned slaughter. The decision also suggests that rather than attempting to prohibit the religious slaughter of animals, a practice explicitly protected by a suite of International Human Rights Instruments, labelling initiatives may be more strategic in informing consumers about the nature of the meat they are purchasing and consuming. In this way, the right to practice one's religion is preserved while also permitting consumers to exercise their purchasing decisions in a manner consistent with their ethical principles. Such labelling initiatives may be particularly relevant in circumstances where meat products from un-stunned animals are by-passing Halal and Kosher food chains and entering wider domestic markets. The debate continues.

\section{Bibliography}

- CANTARERO, L., ESPEITX, E., LACRUZ, MG. et al. Human Food Preferences and Cultural Identity: The Case of Aragon (Spain) (2013) 48 International Journal of Psychology

- COGHLAN, A, Animals Feel the Pain of Religious Slaughter, 13 October 2009, New Scientist

- D'AMICO, P., VITELLI, N. et al, Meat from Cattle Slaughtered Without Stunning Sold in the Conventional Market Without Appropriate Labelling: A Case Study in Italy (2017) 134 Meat Science 1

- FAROUK, M., PUFPAFF, K., AMIR, M., Industrial Halal Meat Production and Animal Welfare: A Review (2016) 120 Meat Science 60

- GIBSON, TJ., JOHNSON, CB., MURRELL, JC., HULL, CM., MITCHINSON, SL., STAFFORD, KJ., JOHNSTONE, AC., MELLOR, DJ., Electroencephalographic Responses of HalothaneAnaesthetised Calves to Slaughter by Ventral-Neck Incision Without Prior Stunning (2009) 57 (2) New Zealand Veterinary Journal 77

- GLISZCZYNSSKA-GRABIAS, A., SADURSKI, W., The Law of Ritual Slaughter and the Principle

\footnotetext{
${ }^{30}$ Council Regulation (EC) No 834/2007 of 28 June 2007 on organic production and labelling of organic products and repealing Regulation (EEC) No 2092/91

${ }^{31}$ Commission Regulation (EC) No 889/2008 of 5 September 2008 laying down detailed rules for the implementation of Council Regulation (EC) No 834/2007 on organic production and labelling of organic products with regard to organic production, labelling and control.

${ }^{32}$ Oeuvre d'assistance aux bêtes d'abattoirs v Ministre de l'Agriculture et de l'Alimentation \& ors, European Court of Justice Case C-497/17 (Judgement 26 February 2019) at [32].

${ }^{33}$ Ibid at [47].

24 Derecho Animal. Forum of Animal Law Studies, vol. 10/2
} 
of Religious Equality (2016) 4 Journal of Law, Religion and State 233

- GREGORY, NG., FIELDING, HR.,VON WENZLAWOWICZ, M.,VON HOLLEBEN, K., Time to Collapse Following Slaughter Without Stunning in Cattle (2010) 85 Meat Science 66

- GRIM. B., KARIM, M., The Future of the Global Muslim Population: Projections for 2010-2030, Pew Research Centre, Washington, United States. <https://www.pewforum.org/2011/01/27/thefuture-of-the-global-muslim-population/> (accessed 7 April 2019)

- HEMSWORTH, PH., FISHER, AD., MELLOR, DJ., JOHNSON, CB., A Scientific Comment on the Welfare of Sheep Slaughtered without Stunning, 14 July 2009 at paragraph 3

- KURTH, L., GLASBERGEN, P., Dealing with Tensions of Multiculturalism: The Politics of Religious Slaughter in the Netherlands (2017) 20(4) European Journal of Cultural Studies 413

- LERNER, P., RABELLO, A., The Prohibition of Ritual Slaughtering and Freedom of Religion of Minorities (2006/2007) 22 Journal of Law and Religion 1

- LEVER, J., PUIG DELlA BELlACASA, M., The Development of Halal and Kosher Meat Markets in the UK, 2010, The University of Huddersfield

$<$ https://pure.hud.ac.uk/ws/portalfiles/porta1/14280072/factsheet_market_uk.pdf $>$ (accessed 7 April 2019)

- MIELE, M., Killing Animals for Food: How Science, Religion and Technologies Affect the Public Debate About Religious Slaughter (2016) 1 Food Ethics 47

- STEIN, B., It's Not Just About the Knife: Religious and Secular Killing for Meat (2015) 1 UniSA Student Law Review 18

- WILliamS, E., DEMELlO, M., Why Animals Matter: The Case for Animal Protection, 2007, Prometheus Books, New York, United States

- ZOETHOUT, C., Ritual Slaughter and the Freedom of Religion: Some Reflections on a Stunning Matter (2013) 35(3) Human Rights Quarterly 651

\section{Court cases}

- Cha'are Shalom Ve Tsedek v. France App No. 27417/95 (ECtHR, 27 June 2000)

- Oeuvre d'assistance aux bêtes d'abattoirs v Ministre de l'Agriculture et de l'Alimentation \& ors, European Court of Justice Case C-497/17 (Judgement 26 February 2019)

\section{Regulations}

- Commission Regulation (EC) No 889/2008 of 5 September 2008 laying down detailed rules for the implementation of Council Regulation (EC) No 834/2007 on organic production and labelling of organic products with regard to organic production, labelling and control

- Council Regulation (EC) No 834/2007 of 28 June 2007 on organic production and labelling of organic products and repealing Regulation (EEC) No 2092/91

\section{Other references}

- Council Agrees on New Labelling Rules for Food, Council of the European Union, 7 December 2010.

- $<$ http://www.consilium.europa.eu/uedocs/cms data/docs/pressdata/en/lsa/118258.pdf $>$ (accessed 8 April 2019)

- European Commission, DG Health and Food Safety, Study on Information to Consumers on the Stunning of Animals (2015) Final Report

$<$ http://www.ceasc.com/Images/Content/2643\%20Appendices.pdf $>$ (accessed 7 April 2019)

- Federation of Veterinarians of Europe, Slaughter of Animals Without Stunning, FVE02/104, 2002 $<$ https://www.fve.org/cms/wp-content/uploads/fve_02_104_slaughter_prior_stunning.pdf $>$ (accessed 7 April 2019)

- Liga van Moskeeën en Islamitische Organisaties Provincie Antwerpen VZW Case C-426/16, 29 May 2018.

- New EU Labels for Halal and Kosher Foods Spark Anger, The National, 26 December 2010 $<$ https://www.thenational.ae/world/europe/new-eu-labels-for-halal-and-kosher-foods-spark-anger-

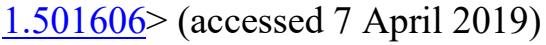

- On the Proposal for a Regulation of the European Parliament and of the Council on the Provision of 
Food Information to Consumers 16 June 2010

$<$ http://www.europarl.europa.eu/sides/getDoc.do?type=REPORT\&reference=A7-2010-

0109\&language $=\mathrm{EN}>($ accessed 7 April 2019)

- Shechita UK, A Guide to Shechita, May 2009, at p $3<$ https://www.shechitauk.org/wpcontent/uploads/2016/02/A_Guide_to_Shechita_2009_01.pdf 